\title{
HIV-1 Antibody Measurement
}

National Cancer Institute

\section{Source}

National Cancer Institute. HIV-1 Antibody Measurement. NCI Thesaurus. Code C74713.

The determination of the antibody reaction of a sample to the HIV-1 virus. 